situar al niño en el asiento central trasero, siempre que sea posible, y ajustar bien los cinturones para reducir la movilidad lateral de la cabeza.

Los niños sentados en el asiento delantero pueden morir o sufrir lesiones graves provocadas por las bolsas de aire (air bags), incluso en accidentes menores. El inflado instantáneo de las bolsas se ha equiparado a una colisión a $300 \mathrm{~km} / \mathrm{h}$. Los niños situados en la zona de inflado de la bolsa pueden sufrir lesiones craneales y medulares mortales. Los niños de menos de 13 años deben ir en el asiento trasero, lejos de las bolsas de aire. La experiencia actual con las bolsas de aire laterales es todavía escasa. Las bolsas de aire traseras pueden causar lesiones graves a niños de hasta 6 años. Es recomendable evitar las bolsas de aire traseras en automóviles en los que viajen niños $\mathrm{y}$, de hecho, en los EE. UU., la política actual es vender los automóviles con estas bolsas desactivadas.

Los modelos de automóviles más recientes disponen de nuevos sistemas que facilitan la instalación de los asientos de seguridad para niños (sistemas LATCH o isofix) y proporcionan un anclaje más seguro que los cinturones de seguridad.

En resumen, los niños deben sentarse en el asiento trasero del automóvil, deben ir sujetos por un dispositivo apropiado para su edad y peso que esté fijado adecuadamente, y deben sentarse lejos de las bolsas de aire. (Howard AW. Automobile restraints for children: a review for clinicians. CMAJ 2002;167:769-773.)

\section{La obesidad en los adultos de los Estados Unidos (1999-2000)}

En Estados Unidos de América (EE. UU.) se vienen realizando encuestas nacionales de salud y nutrición (National Health and Nutrition Examination Surveys) desde la década de los sesenta. La tercera de estas encuestas (NHANES III; 1988-1994) reveló que la prevalencia de la obesidad, definida como un índice de masa corporal (IMC) $\geq 30$, había aumentado en cerca de $8 \%$, después de haberse mantenido relativamente estable entre 1960 y 1980. En este artículo se describen los resultados de la última NHANES (1999-2000) con respecto a las tendencias de la prevalencia de la obesidad y de la distribución de frecuencias del IMC.

Los procedimientos utilizados en la selección de la muestra y en la realización de las entrevistas y los exámenes fueron similares a los de las encuestas anteriores. Este informe se basa en los datos de 4115 adultos de ambos sexos. El sobrepeso se definió como un IMC $\geq 25$, la obesidad como un IMC $\geq 30$ y la obesidad extrema como un IMC $\geq 40$.
La prevalencia de la obesidad se mantuvo relativamente constante entre 1960 y 1980, pero aumentó en la NHANES III (1988-1994). Los datos más recientes (NHANES 1999-2000), muestran un nuevo aumento de la prevalencia de la obesidad en ambos sexos y en todos los grupos de edad.

La prevalencia de la obesidad ajustada por edad fue de 30,5\% en la NHANES 1999-2000, frente a $22,9 \%$ en la NHANES III (1988-1994) $(P<0,001)$. La prevalencia del sobrepeso también aumentó del 55,9 a $64,5 \%(P<0,001)$, al igual que la de la obesidad extrema, de 2,9 a $4,7 \%(P=0,002)$.

Los aumentos observados entre la NHANES II (1974-1980) y la NHANES III (1988-1994) fueron estadísticamente significativos en todos los grupos de edad en ambos sexos, y lo mismo ocurrió con los aumentos observados entre la NHANES III (1988-1994) y la NHANES 1999-2000; la única excepción fue el grupo de hombres de 40 a 59 años, en el que también se observó un aumento, pero no significativo. El aumento observado entre la NHANES III (1988-1994) y la NHANES 1999-2000 fue casi tan grande como el observado entre la NHANES II (1974-1980) y la NHANES III (1988-1994).

La prevalencia de la obesidad y de la obesidad extrema también aumentó entre la NHANES III (1988-1994) y la NHANES 1999-2000 en todos los grupos étnicos analizados: blancos no hispanos, negros no hispanos y estadounidenses de origen mexicano. En general, los aumentos fueron similares en los tres grupos, aunque hubo una tendencia no significativa hacia un mayor aumento en las mujeres negras no hispanas. Más de 50\% de las mujeres negras no hispanas de 40 años o más eran obesas, y más de $80 \%$ tenían sobrepeso.

También se analizó la distribución poblacional del IMC. En los hombres de 60 a 79 años, dicha distribución se desplazó a la izquierda entre la NHANES III (1988-1994) y la NHANES 1999-2000, pero el desplazamiento fue mayor en los percentiles más altos de la distribución. También se observaron cambios similares en los hombres y mujeres de 20 a 39 y 40 a 59 años. En las mujeres de 60 a 79 años los desplazamientos fueron más uniformes.

El aumento de la prevalencia del sobrepeso y la obesidad plantea interrogantes importantes sobre las implicaciones sanitarias de esta tendencia, dado que la obesidad es un factor de riesgo de muchas enfermedades crónicas, como la diabetes, la hipertensión, la hipercolesterolemia, los accidentes vasculares cerebrales, las cardiopatías, algunos cánceres y las enfermedades articulares. De todas estas enfermedades, la diabetes podría ser la más estrechamente relacionada con la obesidad y, de hecho, su prevalencia parece haber aumentado a medida que ha aumentado la prevalencia de la obesidad. En 
cambio, la prevalencia de otras enfermedades, como la hipercolesterolemia y la hipertensión, disminuyó entre la NHANES II (1974-1980) y la NHANES III (1988-1994), a pesar del aumento de la prevalencia de la obesidad. La mortalidad cardiovascular total y la mortalidad por cardiopatía coronaria y accidentes vasculares cerebrales también han disminuido. Aunque los posibles beneficios de reducir el sobrepeso y la obesidad son un tema de gran importancia para la salud pública, los resultados de estas encuestas indican que puede ser difícil frenar la tendencia al aumento de su prevalencia en los EE. UU. (Flegal KM, Carroll MD, Ogden CL, Johnson CL. Prevalence and trends in obesity among US adults, 1999-2000. JAMA 2002; 288: 1723-1727.)

\section{In Memoriam}

João Yunes

23 August 1936 - 26 September 2002

We regret to announce the death of Dr. João Yunes. His family, friends, and professional colleagues will fondly remember him and the contributions that he made to public health. During his professional career, Dr. Yunes served in several full-time positions with the Pan American Health Organization (PAHO) from 1987 to 1997, including as Director of the PAHO Division of Health Promotion and Protection. A native of Brazil, he received an M.D. degree from the University of São Paulo; a master's degree in public health from the University of Michigan, in the United States of America; and a doctoral degree in social pediatrics from the University of São Paulo. He held positions with the Ministry of Health of Brazil that included Advisor in Maternal and Child Health and National Secretary of Health. He served as Secretary of Health of the state of São Paulo from 1983 to 1987. In June 1987 he was appointed as PAHO/WHO Representative in Cuba, and in May 1989 he became Coordinator of the Maternal and Child Health Program at the PAHO Headquarters in Washington, D.C. After leaving PAHO in 1997, he served in the Ministry of Health of Brazil and in May 2001 accepted the position as Director of the School of Public Health of the University of São Paulo. He published extensively in the scientific literature. Among his special areas of interest were violence as a public health issue; the health of infants, children, and adolescents; maternal health; and the organization of health services. 